\title{
Monitoramento de Prontuários no Faturamento
}

AUTORES: Carina Tamazeli Marcondes, Vilma Neri Shinsato, Ayako Utimura Sueta e

\section{INTRODUÇÃO}

O Monitoramento do prontuário é realizado para garantir os registros a cerca da assistência prestada ao paciente pela equipe interdisciplinar conforme a recomendação do Núcleo Segurança do Paciente e ao mesmo tempo garantir a sustentabilidade da instituição, prevenindo glosas.

\section{OBJETIVO}

Reduzir o número de não conformidades nos registros do prontuário para assegurar a fidedignidade dos dados contidos.

\section{METODOLOGIA}

O prontuário médico é encaminhado ao faturamento:

- Como primeira barreira, as informações do prontuário são analisadas pelos assistentes de faturamento através da conferência dos dados que impactam na cobrança da conta hospitalar, as informações são processadas com foco no recebimento.

- Como segunda barreira os dados são monitorados pela auditoria de enfermagem, identificando e solicitando as unidades de internações justificativas dos procedimentos, corrigindo situações de risco em relação à conta faturada.

As informações são organizadas de forma clara e transparente, trabalhando com a prevenção de glosas e satisfação da fonte pagadora, focada na qualidade do atendimento.

\section{RESULTADOS}

Os dados são monitorados e acompanhados através do Indicador de Prontuário Não Conforme, onde são realizadas reuniões mensais com os gestores das unidades para orientação das informações com acompanhamento e ações da Educação Continuada e Núcleo de Segurança do paciente para melhoria das informações.
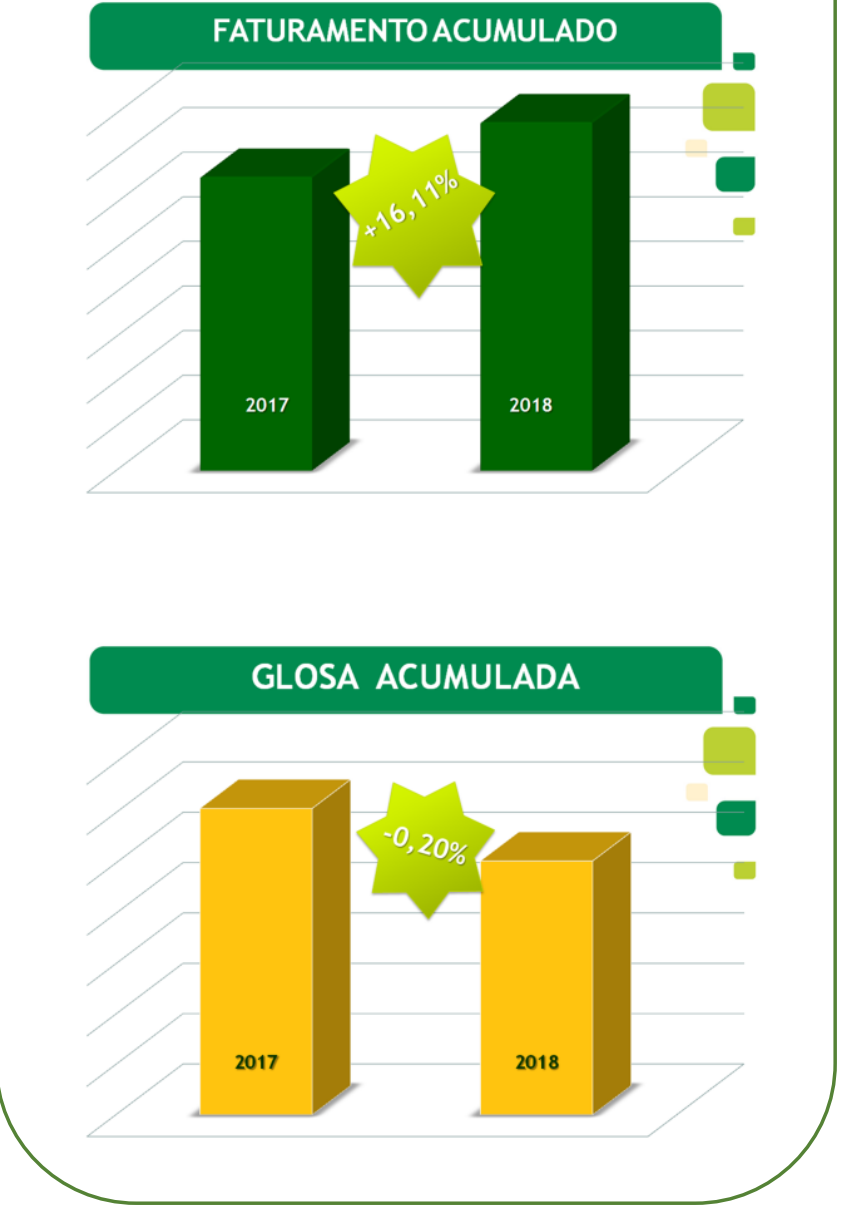

\section{CONCLUSÃO}

Comparando o ano de 2017 e 2018, tivemos um aumento no faturamento em $16,11 \%$ e reduzimos o percentual de glosa em $0,20 \%$. 